\title{
Diffusion of Innovation Theory and an Implementation on Enterprise Resource Planning Systems
}

\author{
Yaşar Akça ${ }^{1} \&$ Gökhan Özer ${ }^{2}$ \\ ${ }^{1}$ Faculty of Economics and Administrative Sciences, Bartın University, Bartın, Türkiye \\ ${ }^{2}$ School of Management, Gebze Institute of Technology, Kocaeli, Türkiye \\ Correspondence: Yaşar Akça, Faculty of Economics and Administrative Sciences, Bartın University, 74100 \\ Bartın, Türkiye. Tel: 90-378-223-5339. E-mail: yakca@bartin.edu.tr
}

Received: February 8, 2014

doi:10.5539/ijbm.v9n4p92

\begin{abstract}
Enterprise Resource Planning (ERP) systems are adopted by many companies. By means of setting up this management information system software, significant organizational activities are accomplished while many others remain unachieved. This article grounds on utilization of variables of Diffusion of Innovation (DOI) Theory (Rogers, 2003) in accomplished adoptions of ERP systems. DOI Theory can be carried out in terms of guiding ERP application. Attained evidences reveal that variables in theory affect ERP success positively as well as organizational performance. Considering variables of DOI Theory will accelerate the adoption of innovation. The major contribution of this article to the science literature is to define the essential building blocks of application of ERP software system to the organization.
\end{abstract}

Keywords: diffusion of innovations theory, user characteristics, innovative characteristics, organizational characteristics, environmental characteristics, enterprise resource planning implementation success, perceived organizational performance

\section{Introduction}

Companies use management information systems based on computer software, particularly in planning, controlling, coordination and decision making actions. It is possible to collect, store, deliver, analyze information and process data through aforesaid computer software. Thereby, products consisting of computer hardware and software are termed as management information systems.

Realization of factors affecting successful adoptions and usage of innovations to companies such as flexible manufacturing systems, robotic systems and management information systems is a significant scientific research issue (Frambach \& Schillewaert, 2002, p. 163). From this point forth, critical factors set which is contributing to organizations' success of implementation endeavor of information technologies needs to be defined. Presenting aforementioned critical success factors will make contribution to the realization process of utility of information systems and improving company performance. A failure of these definitions of critical factors will cause inactive information system investments and unsuccessful processes.

Implementation of ERP projects is a sophisticated issue. It represents the widest and the most complex practices. The success of ERP systems is determined by configuration considerably. It is essential to plan configuration resplendently and manage carefully for the success. There are no consensuses by researchers on critical factors set (Zhang, Lee, Zhang \& Banerjee, 2003, p. 2) although they define various variables which can contribute to successful ERP application (Motwani, Mirchandani, Madan \& Gunasekaran, 2002, p. 83).

The purpose of this article is to manifest that the usage of DOI Theory variables as critical success factors needs to be considered throughout adoption of ERP system software, which is an information technology innovation, to the company. Regarding variables representing DOI Theory in ERP implementation success will lead producers, dealers, consultancy service providers of this product and potential ERP users thinking of investment on this software. These variables will define and analyze positive or negative effects on organizational performance empirically. 
The article is consisting of four chapters. In the first phase, variables of DOI Theory are presented. In the second phase, ERP management information systems are introduced. In the third chapter, the model is clarified and hypothesis is set.

There are two sides of presented model at stake: one side includes successful set up of ERP software, and the other side contains promoting organizational abilities (perceived organizational performance) by means of setting up software. At the last phase, correlations between variables have been practiced to test hypotheses.

\section{Diffusion of Innovation Theory}

Rogers (2003), DOI Theory has prevailing usage while searching factors affect diffusion of inventions in a social system (Majanja \& Kiplangat, 2005, p. 211). Diffusion is a process of delivering of innovation (new ideas, application, product and technologies) via a specific channel between the members of a social system. According to Rogers (2003, p. 5-6), the theory explains many exogenous factors that affect decision on application of information technology innovation. This theory has been applied in many academic disciplines foremost economy and including health, education, sociology, geography, communication and business (Murray, 2009, p. 110). Information systems has theoretic base for realization of ideas devoted to adoption of its projects (Majanja \& Kiplangat, 2005, p. 213).

Diffusion of innovation, namely uptake of subscribers, is a significant determiner for success of a company (Frambach \& Schillewaert, 2002, p. 163). Rogers (2003) model clarifies the factors affecting innovation adoption by 28 attitudes gathered in five characteristics. Developing an attitude toward innovation is the reason for either approval or denial of innovation. Aforesaid variables are subjective, perceptual measurements which differ according to individuals. To the theory's assertion, when aforementioned variable factors have been applied, the diffusion of innovation will accelerate further. These factors are (Ollila \& Lyytinen, 2003, p. 282-283; Rogers, 2003, p. 26-36, 242-244);

a. Individual factors: The perception of potential user toward information system is substantive determiner of information adoption. In DOI Theory, individual attitude toward innovation determines adoption or denial. If adoption is to be decided, innovation will be applied (Thong, 1999, p. 194). These are elements constitute individual factors:

Own testing: Testing innovation means experiencing it in a limited area. It is necessary to test system to perform information system's function. Resolution of problems is particularly important. Innovation is tried as experimental basis (Ollila \& Lyytinen, 2003, p. 282)

Personal contact network: People trust experiences of their friends.They rely on experiences of their peers, similar to interpersonal networks (Ollila \& Lyytinen, 2003, p. 282).

Own rules and control of job: New ideas should be experienced to reach the advantages of innovation. The innovator has to conduct experimentation with a new idea in order to assure itself that innovation is advantageous (Ollila \& Lyytinen, 2003, p. 282).

Learning by doing: Learning to evaluate the innovation on the basis of experience. It means learning to consider innovations depending on experience. Innovation application that includes less concern and uncertainty will accelerate adoption (Ollila \& Lyytinen, 2003, p. 282).

b. Innovative factors: The judgment of potential users who want to adopt innovation determined by these factors:

Relative advantage: The degree to which an innovation is perceived better than the idea it supersedes. It is a level of perception of that innovation is better (economic, effective, efficient, satisfactory and functional) than previous system (Ollila\&Lyytinen, 2003, p. 282).

Ease of use: The degree to which an innovation is perceived difficult to understand and use. It is the conception of that learning and using innovation is not hard. According to Theory, ease of understanding of innovation will speed up adoption (Ollila \& Lyytinen, 2003, p. 282).

Compatibility: It means that the perception of content of innovation is compatible with present needs, values and business applications, and not to be too complex. Innovations which are not compatible technically require for a change in values. More compatibility will accelerate adoption of new system (Ollila\&Lyytinen, 2003, p. 282).

Visibility: To what extend the innovation is visible to others. Innovation should be able to be test and include visible results. Visible results will reduce doubts for decision of adoption (Ollila\&Lyytinen, 2003, p. 282).

Price: The cost of an innovation (Ollila \& Lyytinen, 2003, p. 282). 
Problemsolver: The desirability of adopting an innovation depends on the problem of the innovation promises to be solved for the adopter. The endeavor of information technology application should handle the problems stemming from company (Ollila \& Lyytinen, 2003, p. 282).

Standard: It means actions that are needed to be followed by producers and users when they begin to use innovation. Manufactures and clients begin to use a standard forcing the user to follow (Ollila \& Lyytinen, 2003, p. 282).

Technological edge: It is superiority of innovation in terms of others (Ollila \& Lyytinen, 2003, p. 282).

c. Task factors: Task factors consist of below sub-branches:

Commercial advantage: The internal or external vendor sells an innovation in a form of a useful product. Afterwards, this product is commercialized (Ollila \& Lyytinen, 2003, p. 282).

User satisfaction: An innovation must match the user needs in the task (Ollila \& Lyytinen, 2003, p. 282).

User resistance: It refers user's endurance to change when user's tasks are in vicious circle. When tasks become difficult, users resist change (Ollila \& Lyytinen, 2003, p. 282).

d. Organizational factors: Some characteristics of organizational factors have an effect on innovation adoption decision. It consists of these variables:

Interpersonal networks: Evaluations of innovations are exchanged between individuals of social system (Ollila \& Lyytinen, 2003, p. 283).

Communication: Exchange of information is informal and unplanned between individuals. This occurs via media or inter-personal channels. By means of communication, it is possible to reveal innovation or to focus on the usage of information (Ollila \& Lyytinen, 2003, p. 283).

Technological experience: It refers technological experiment over a long time period (Ollila \& Lyytinen, 2003, p. 283).

Working teams: Information technologies projects need team combinations. This stuff should be consisted of skillful administrative and technical personnel. Project team should be strengthened to take fast and efficient decisions. Team members should keep primary control over their management (Ollila \& Lyytinen, 2003, p. 283).

Project leaders: An individual who influences clients innovation decisions. They are elected among top managers. Personnel may have to work excessive hours while adopting the administration information system. In addition, accompanying stress may demoralize stuff. Project leaders will fortify project members in this situation (Ollila \& Lyytinen, 2003, p. 283).

Interdependence from others: Adapter of innovation takes benefit of it more than others who will take benefits of innovation in the future. Each adopter increases the utility of the innovation for both future adopters (Ollila \& Lyytinen, 2003, p. 283).

Adopter type: The degree to which an individual is earlier in adopting new ideas than others. This is who adapt the innovation in first place (Ollila \& Lyytinen, 2003, p. 283).

Management hierarchy: an order is given to adopt an innovation (Ollila \& Lyytinen, 2003, p. 283).

Size of organization: Larger organizations are more innovative. It is measured in the number of staff, the amount of actives and size of sell out (Rogers, 2003, p. 379).

e. Environmental factors: Innovations are not independent from environmental factors. The successful transfer of innovation is also dependent on environment (Wejnert, 2002, p. 310). Existence or absence of environmental factors determines the decision of innovation adoption. Environmental factors consist of these elements:

Cultural values: Cultural beliefs concerning change. It represents participation of stuff to the decisions in terms of cooperation, coordination, personal strengthening, organizational vision, open communication, strong leadership, role and mission (Ollila \& Lyytinen, 2003, p. 283).

Technological infrastructure: The maturity of the technological infrastructure. More changes are needed while operating more complex technological structures (Ollila \& Lyytinen, 2003, p. 283).

Community norms: The obedience to norms (Ollila \& Lyytinen, 2003, p. 283).

Funding: Available resources to invest (Ollila \& Lyytinen, 2003, p. 283). 


\section{ERP Systems}

The final pace of the usage of information systems for companies is ERP systems. The largest share is taken by ERP systems among investments for information technologies (Al-Mashari, Al-Mudimigh \& Zairi, 2003, p. 352). ERP systems are package software which provide for integration of software on one particular database in company functions like sell out, materials technical management, production, human resources, administrative control, accounting and finance (Gyampah \& Salam, 2004, p. 732). It combines functional areas in organizations and processes based on information. ERP systems are in use in many industries like production, finance, education, insurance, automotive, banking, health, chemistry, consumption products, retailing, construction, aviation and defense, engineering, electronics, media, petrol, gas, pharmaceutical industry, public sector, service providers, communication, transportation and similar (Chung \& Snyder, 2000, p. 25; Siriginidi, 2000, p. 379).

Popularity of ERP derives from combination of efficiency (Note 1) and effectiveness (Note 2) (Chou \& Chang, 2008, p. 149). The purpose of ERP system is to develop organization's performance. It acts as a 'backbone' and 'digital neural system' functions (Mabert, Soni \& Venkataramanan, 2001, p. 76) to organization. Management information system is indispensable (Sheu, Chae \& Yang, 2004, p. 362) and popular for competing companies. It is a trustworthy tool for multi-functionality, branching, and multi-national company administration (Siriginidi, 2000, p. 379). It saves up from production and service costs (Zhang, Lee, Huang, Zhang \& Huang, 2005, p. 57). It is possible to shortening cycle time, promoting on customer satisfaction, quality, and reaching faster to data. It is both possible to use as an only module representing one company function or with other modules involving multi company functions. With better resource management, increasing in profitableness, elasticity, improvement in decision making, planning and performance, integration of work process and company functions are possible. It supports growing of company, business associations, cost leadership, production differentiation and sets external contacts.

\section{Research Model}

Successful ERP Model includes 13 different variables under extends of user characteristics, innovative characteristics, organizational characteristics and environmental characteristics in which organization is being active. These variables are; under the user characteristics extent: user satisfaction and user resistance. Underinnovative characteristics extent: technical compatibility, total quality management and reengineering. Underorganizational characteristics extent: senior management support, consensus on organizational objectives, education and information intensity. Underenvironmental characteristics extent: competitive pressure and environmental uncertainty. Effects of counted variables on ERP information system's application success and perceived operational performances, which are dependent variables will be examined (see Figure 1). If the presented model would be considered during application, ERP adoption in organization will be successful. Under the Individual properties factor group, two variables have been examined: user satisfaction and user resistance. User satisfaction reveals system use (Adamson \& Shine, 2003, p. 443). Because accomplishing satisfaction of user will end up with system use. Adoption of information systems cause changes in organization. For this reason, resistance should be understood and managed.

Innovation characteristics are company's attitude toward innovation, which adopts innovation (Frambach \& Schillewaert, 2002, p. 164). Technical compatibility, total quality management and reengineering are considered. Technical compatibility variable is pointed out by Rogers (2003). Bradford and Florin (2003, p. 207) asserts that they have a contribution to DOI Theory by examining reengineering under innovative characteristics. In this article, total quality management is included in innovative characteristics. Because quality is important part of the innovation process which is applied to promote organizational performance (Keogh \& Bower, 1997, p. 200). By means of the research of last mentioned variable's effect on perceived organizational performance and information technology application success, it contributed DOI Theory in addition. Organizational characteristics are important due to the fact that taking benefits of ERP system applied on organization is only possible if it is compatible with existing organization's values (Ramamurthy, 1994, p. 2251). The first variable that constitutes model's organizational characteristic is senior management support which represents administrators. The second variable is consensus on organizational purposes and the third is education. These variables are taken from DOI Theory. The fourth variable is information intensity. Including information intensity to organizational characteristics is pertain to this article and asserts a contribution to DOI Theory.

Another determiner of Innovative attitude is environmental characteristics. Organizations change by reactions to changes that are taking place around their environment (Dixon, Arnold, Heineke, Kim \& Mulligan, 1994, p. 98). Organizations obtain various inputs from environment and give their products to the environment. By that way, 
organizational structure became compatible with its environment. The most popular variables in literature are competition pressure and environmental uncertainty (Choe, Lee \& Park, 1998, p. 137; Thong, 1999, p. 193).

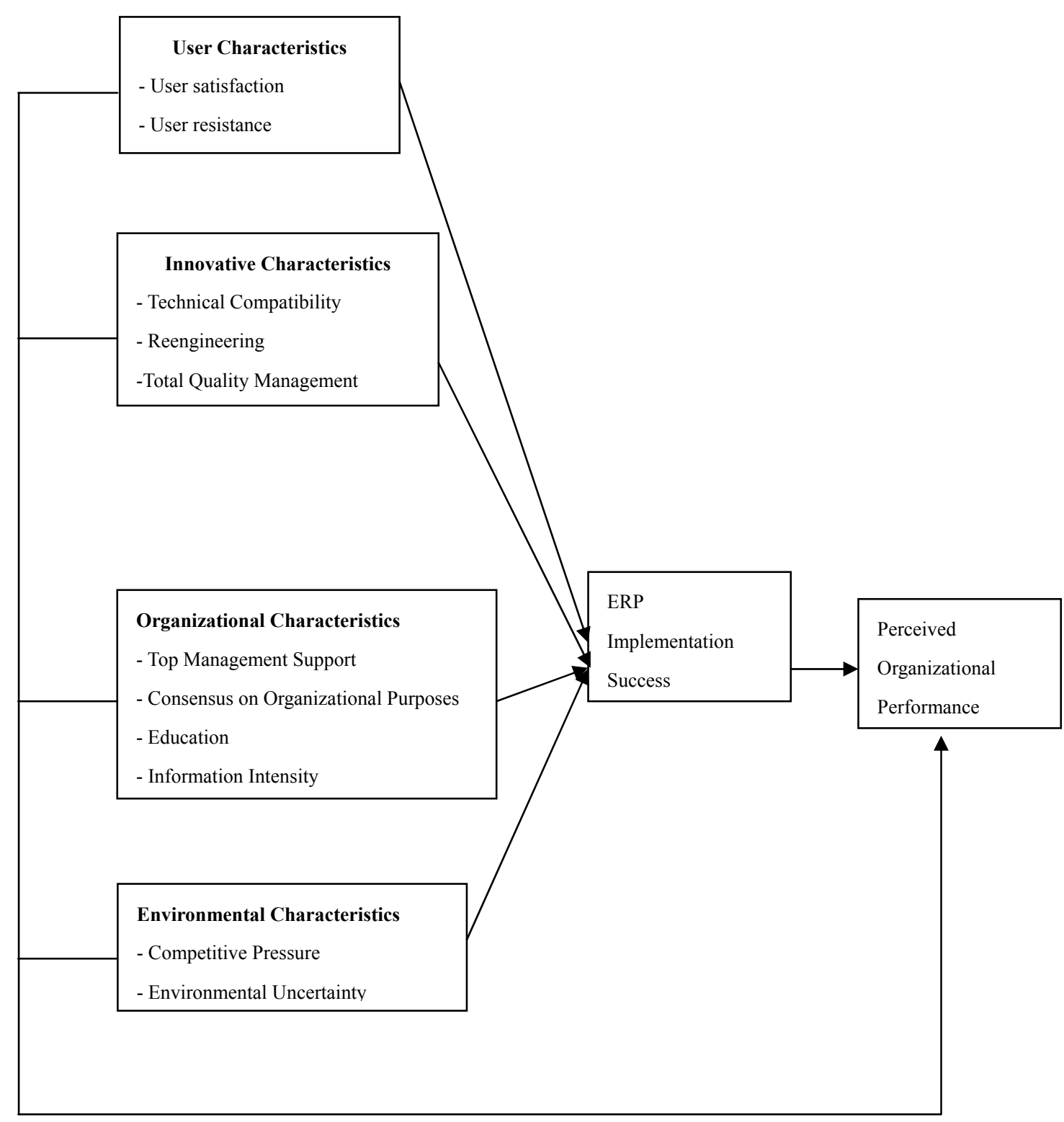

Figure 1. Research model

\subsection{User Characteristics}

User characteristics affect information system's performance. User is a person who has the administrative responsibility and uses information technology under work controls (Whyte, Bytheway \& Edwards, 1997, p. 38). In designing, applying and promoting information systems, user and participation of users have a key role. Ignoring system users will bring some problems together. Users provide inputs to system and benefit the outputs of system. Since users are interested in how system affected their business, a successful information system meets the user's expectations (Whyte et al., 1997, p. 38). Researching user's characteristics will ensure approval new information technology; reduce the user's resistance and better understanding of usage of current technology. The ratio of technological problems faced during set up of new information systems is below $\% 10$ and human factor is main reason (Martinsons \& Chong, 1999, p. 126). Two variables are examined under user characteristics factor group: user satisfaction and user resistance. Rogers (2003) pointed out user satisfaction and user resistance variables. 


\subsubsection{User Satisfaction}

It is useful to define satisfaction at first. It refers to attitudes toward factors that affect situation or sum of emotions (Legris, Ingham \& Collerette, 2003, p. 192). User satisfaction means the attitude toward a specific computer application of user who is in interaction with it (Somers, Nelson \& Karimi, 2003, p. 597). The importance of user satisfaction is developing out of that it can cause and increase the use of the system. By this way, it will improve efficiency and lower the costs of the system (Adamson \& Shine, 2003, p. 443). The research results of Igbaria and Tan (1997, p. 113) assert that satisfaction of users is the most important factor that affects the use of the system. Information systems that meet the expectations of users will strengthen the satisfaction. It will thereby, build trust and promote use of information system. Besides that user satisfaction is needed to improve system's design. Tait and Vessey $(1988$, p. 96$)$ interpret the increasing of the user satisfaction as a success of the system.

It is determined in literature (Adamson \& Shine, 2003, p. 444), that user satisfaction and organizational performance are affecting each other deeply. Data results which have been attained by 625 workers of a company carrying on a business in Singapore reveal that user satisfaction is the most significant factor that affects system use (Igbaria \& Tan, 1997, p. 113). Empirical results of the questionnaire study performed in 200 Canadian companies that use ERP system points out that user satisfaction on ERP systems are at higher levels than others (Zviran, 2003, p. 1). Another questionnaire study performed with 170 Dutch information administrator indicates that user satisfaction is making more contribution to organizational performance (Gelderman, 1998, p. 17). In a sample consisting of 107 workers of an investment bank, Lucas and Spitler (1999, p. 295), who are expecting to see positive correlation between use and performance, reached evidences that support their expectation with significance level of $1 \%$ (Lucas \& Spitler, 1999, p. 302). After these explanations following hypothesis will be tested:

$\mathrm{H}_{1 \mathrm{a}}$ : There is a positive correlation between user satisfaction and ERP implementation success.

$\mathrm{H}_{1 b}$ : There is a positive correlation between perceived organizational performance and user satisfaction.

\subsubsection{User Resistance}

Resistance refers to unwillingness of operating system as an opposite reaction towards estimated change (Adams, Berner \& Rousse, 2004, p. 56). Resistance should be understood and managed, since adoption of ERP requires changes (Hong \& Kim, 2002, p. 26) in organizations as it does in culture, structure, people, mission and technology. Resistance reactions against information systems are coming out in following forms: passive endurance which means lower system use (not attaining computer lessons), complaints about inability of using computer, refusing to use new system, stress, dissatisfaction, fear (Martinko, Henry \& Zmud, 1996, p. 314), being late for work, disparagement of system, data ruins (Adams et al., 2004, p. 56), decrease of work efficiency, walk out, self-isolation from system, faulty data input, mistrust of computer outputs, poor morale (Hirschheim \& Newman, 1988, p. 399). Main strategies to decrease resistance are user education, communication, user participation, guidance and explanation of benefits that are expected from system (Adams et al., 2004, p. 57). 106 questionnaire results attained from 34 companies from South Korea which are adopted ERP systems demonstrates that user resistance is affecting organizational performance significantly in a negative way (Hong \& Kim, 2002, p. 35). Bradford and Florin (2003, p. 208), who are examining for effects of user resistance over organizational performance reached the assertion of that user resistance for new technologies bring along low satisfaction and low system performance.

$\mathrm{H}_{2 \mathrm{a}}$ : There is a negative correlation between user resistance and ERP implementation success.

$\mathrm{H}_{2 \mathrm{~b}}$ : There is a negative correlation between user resistance and perceived organizational performance.

\subsection{Innovative Characteristics}

Innovation characteristics in literature are accepted as an important determiner decision of adoption on information technology to the organization (Thong, 1999, p. 187). Innovative characteristics are the attitudes of adapter company towards innovation. Innovations, thereby requires for change in an organization by that a response is given to domestic and external environment (Frambach \& Schillewaert, 2002, p. 164). Innovation in respects of this character is a tool for resolutions against company problems. There are researches that supports the assertion of that innovation has a contribution to company performance (Hult, Hurley \& Knight, 2004, p. 429 ) and innovation characteristics has a positive correlation with company performance (Calantone, Çavuşgil \& Zhao, 2002, p. 516). The most significant innovative characteristics effecting ERP applications are technical compatibility, reengineering and total quality management. 


\subsubsection{Technical Compatibility}

Technical compatibility refers to the level of coherence of new systems with organization's present technology and systems (Palvia, Sharma \& Conrath, 2001, p. 249). Technical compatibility is coming along with innovative attitude characteristic in information systems (Fichman, 2001, p. 434). The main purpose of information technology architecture is to avoid incompatibility to realize integration (Keen, 1994, p. 105). It is easy to integrate ERP technology to new systems. ERP packages present best business application as it is regarding the essential needs for present industry. Au and Enderwick (2000, p. 270), in a questionnaire study that 298 companies participated, points out that perception of foreign technology is compatible with present technology affects attitudes toward adoption in a positive way. Frambach (1993, p. 27), who assert that innovation's technical compatibility has a positive relation with adoption ratio, propounds this reality can be generalized.

$\mathrm{H}_{3 \mathrm{a}}$ : There is a positive correlation between ERP implementation success and technical compatibility.

$\mathrm{H}_{3 \mathrm{~b}}$ : There is a positive correlation between perceived organizational performance and technical compatibility.

\subsubsection{Reengineering}

The definition of the term of reengineering is made by Hammer and Champy (1993, p. 381). Reengineering means rethinking of work processes fundamentally to succeed in critical performance measurements like costs, quality, service, distribution, flexibility, work satisfaction, speed and re-planning of management process radically. Reengineering by ERP information system is important in terms of enabling competition by protecting self-skill, decreasing storage, preserving market share, removing idle time (Siriginidi, 2000, p. 377), important reductions in mistakes, time processes, profitability, efficiency, increasing customer satisfaction, better organizational effectiveness and efficiency (Ahadi, 2004, p. 2), enhancement of the quality of presented product and service (Raymond, Bergeron \& Rivard, 1998, p. 73). On the other hand, not to be able to meet the organization needs requires reexamination of ERP software package. Work processes should be reexamined in order to provide compatibility of software with organization's processes. Changing software according to company will raise costs and mistakes (Ngai et al., 2008, p. 551). In this context, these arguments can be presented.

$\mathrm{H}_{4 \mathrm{a}}$ : There is a positive correlation between reengineering and ERP implementation success.

$\mathrm{H}_{4 \mathrm{~b}}$ : There is a positive correlation between reengineering and perceived organizational performance.

\subsubsection{Total Quality Management}

Total quality management (TQM) programs are one of the important approaches in order to promote organizational performance. TQM is a set of principles and philosophy of management that based on the belief of constant company-wide improvement accompanying work processes in production of products, services with the participation of workers, leading of organization's management and considering costumers, people's expectations (Dale \& Cooper, 1994, p. 20). TQM centers on zero mistakes, satisfaction of customer, continuously improvement and focusing on processes (Palvia et al., 2001, p. 249). Cooperation between functions and change ever forgoing after communication promotes organizational performance and quality. Dale and Cooper (1994, p. 20) qualify TQM as a strategy that affects organization's success and competitive performance. There is a consensus on that TQM tends to cause better performance in organizations (Kassicieh \& Yourstone, 1998, p. 36). Kuei, Madu, Lin and Lu (1995, p. 123) work reveals positive interaction between TQM and organizational performance. In empirical work of Pearson, McCahon and Hightower (1995, p. 251), TQM made a positive contribution on information technology. This hypothesis will be tested:

$\mathrm{H}_{5 \mathrm{a}}$ : There is a positive correlation between TQM and ERP implementation success.

$\mathrm{H}_{5 \mathrm{~b}}$ : There is a positive correlation between perceived organizational performance and TQM.

\subsection{Organizational Characteristics}

The organizational characteristics are the substantive exterminator of adoption and integration of information system to the organization. Because, taking benefits of information system is upon the compatibility of organization with present value system (Ramamurthy, 1994, p. 2251). Positive contribution is expected to innovation from organizational characteristics (Brandyberry, 2003, p. 152).

\subsubsection{Top Management Support}

Top management support in ERP application success means to be realized of information system's importance by senior managers and level of participation of senior management to information system activities (Raghunathan, Apigian, Raghunathan \& Tu, 2004, p. 461-462). Approval should be received from top 
managers before adoption of ERP. Top managers should be willing to allocate valuable resources for ERP application endeavors (Ngai et al., 2008, p. 556). According to researches, direct involvement of senior managers to ERP system application affects organization's system performance positively (Raghunathan et al., 2004, p. 468). Literatures (Al-Mashari et al., 2003, p. 357) point out that performance of organization is also related to top manager's attitude. Upon these findings and theoretic information, these hypotheses will be tested:

$\mathrm{H}_{6 \mathrm{a}}$ : There is a positive correlation between top management support and ERP implementation success.

$\mathrm{H}_{6 \mathrm{~b}}$ : There is a positive correlation between top management support and perceived organizational performance.

\subsubsection{Consensus on Organizational Purposes}

As an output of decision making process, consensus means the reasonable decision taken as a group by compromising all sides (Dess \& Origer, 1987, p. 313). It helps the implementation of political and strategic decisions. It makes purposes become measurable by creating course of action. It elicits sharing of information, announcing ideas, perceiving company's competitive environment, purpose and strategies (Dess \& Priem, 1995, p. 401). Participation of users in process of designing and applying of information system increase consensus and provide better coordination (Dooley, Fryxell \& Judge, 2000, p. 1238). In a questionnaire study with participation of hospital administrators made by Dooley et al. (2000, p. 1239), who test the hypothesis of that consensus increases successful adoption of application and improve company performance. It is revealed that consensus is positively related with application success. In another empirical study with participation of 88 companies, it is revealed that consensus of top managers on strong/weak sides of company is affecting organizational performance positively (Hrebiniak \& Snow, 1982, p. 1139). With the aid of a research study exerted by a questionnaire replied by 74 managers from 19 firms, it is supported that there is a positive correlation between 'consensus on organizational purposes' and measures of firmat a level of $5 \%$ significance (Dess, 1987, p. 270). In Bradford and Florin's (2003, p. 215) empirical study, it is asserted that consensus causes active application, following of system's success and ultimately perceived organizational performance. Two hypotheses will be tested about this variable.

$\mathrm{H}_{7 \mathrm{a}}$ : There is a positive correlation between consensus on organizational purposes and ERP implementation success.

$\mathrm{H}_{7 \mathrm{~b}}$ : There is a positive correlation between consensus on organizational purposes and perceived organizational performance.

\subsubsection{Training}

Training is the process of realizing desired behavioral pattern for individual (Knol \& Stroeken, 2001, p. 233). It has a substantive role use and acceptance of information technology (Stratman \& Roth, 2002, p. 603). ERP training teaches users the effective use of ERP system in their daily life. The base of ERP system is human. The ERP education's aim is to provide higher organizational success by ensuring information transfer. One particular reason of the failure of ERP system is inadequate training (Al-Mashari et al., 2003, p. 359).

Zhang and his friends (2003, p. 6), who tested hypothesis of that education has a positive effect on ERP application success, found supporting findings from the data received from 47 companies. Birley and Westhead (1990, p. 540), who examined hypothesis of that education has a positive relation with growth and high performance, reported positive correlation with significance of $1 \%$.

In a study compensating 845 Canadian companies, Thornhill (2006, p. 693), examined the hypothesis of that level of training investment of company will come along with positive effect to company's performance.Results that support existence of positive relation significantly (Thornhill, 2006, p. 697). These hypotheses will be tested to find out training's role:

$\mathrm{H}_{8 \mathrm{a}}$ : There is a positive correlation between training and ERP implementation success.

$\mathrm{H}_{8 \mathrm{~b}}$ : There is a positive correlation between training and perceived organizational performance.

\subsubsection{Information Intensity}

Information intensity refers to the level of storage cultivation of information in company products and activities (Hu \& Quan, 2005, p. 43). It is also defined as the quantity of information that is needed to use, produce or improve of producer service (Bhatt \& Stump, 2001, p. 35). Information, which is taken product or service, points out the level of information intensity of that product or service (Thong, 1999, p. 196). Information intensity shapes the role of information technologies in organizations. It is found out that information intensity come along with adoption and use of information system in organizations (Wang, 2001, p. 432). In empirical study of Thong (1999, p. 203-205), attained results support that information intensity of product or service 
accompanies success of information system's adoption significantly. These hypotheses will be tested in order to find out affection of information intensity variable.

$\mathrm{H}_{9 \mathrm{a}}$ : There is a positive correlation between information intensity and ERP implementation success.

$\mathrm{H}_{9 \mathrm{~b}}$ : There is a positive correlation between information intensity and perceived organizational performance.

\subsection{Environmental Characteristics}

Environment refers to a geographical area out of boundaries of company activities (Dixon et al., 1994, p. 98). Organizations change by means of to be reactively their environmental change. So that, organization's structure and process become compatible with its environment. Environment provides resources that company needs.

\subsubsection{Competitive Pressure}

Competition means that business environment in which company is being active (Thong, 1999, p. 196). Competitive pressure is the cause of activation of company to start product and process innovations (Boone, 2000, p. 552). Perceived competitive pressure canalize company to new standards affecting the process of production or services related to environment, performance, quality and security (Montalvo, 2004, p. 318). Also, ERP systems provide for electronic trade, realize integration of information between customers and supply chain. Various findings exist in literature about positive relation between competitive pressure and perceived organizational performance, positive affection of competitive pressure on adoption of innovation (Premkumar \& Roberts, 1999, p. 472). Poston and Grabski (2001, p. 273), examining the reason of ERP adoption of companies, assert that companies tend to adopt ERP as a reaction to industrial players changing their system into ERP. Under these circumstances following hypothesis can be asserted.

$\mathrm{E}_{10 \mathrm{a}}$ : There is a positive correlation between competitive pressure and ERP implementation success.

$\mathrm{E}_{10 \mathrm{~b}}$ : There is a positive correlation between competitive pressure and perceived organizational performance.

\subsubsection{Environmental Uncertainty}

Environmental uncertainty means inability to see affections of external environment (Hoque, 2004, p. 489) like industrial relations, economic environment, government policies, rivals, technological processes, globalization, legislative regulations, suppliers, customers on organization robustly; confusion of correlation between relevant and irrelevant data (Buchko, 1994, p. 411); absence of foresight (Cohen, 2001, p. 20); information absence about reason-cause relations (Ashill \& Jobber, 1999, p. 523). It is being reported in literature that there is a positive correlation between perceived environmental uncertainty and economic performance of the company. Increasing environmental uncertainty incites adoption of innovations (information technology). Perceived environmental uncertainty affects organizational decisions as an important variable on organizational processes, structures and performance. According to Choe and his friends (1998, p. 137), there is a positive correlation between application level of information system and perceived environmental uncertainty. Also Stanwick and Pleshko (1995, p. 192), support the assertion of positive relation between the level of adoption of information system and perceived environmental uncertainty. Considering these findings, following hypothesis can be asserted.

$\mathrm{H}_{11 \mathrm{a}}$ : There is a positive correlation between environmental uncertainty and ERP implementation success.

$\mathrm{H}_{1 \mathrm{~b}}$ : There is a positive correlation between environmental uncertainty and perceived organizational performance.

\subsection{ERP Implementation Success}

The success of information system means to realize potential benefits attained from application of information system. These are information technology system involving planned purposes particularly, ensuring positive attitude of users toward information technology. Helping users to accomplish their tasks means success (Au, Ngai \& Cheng, 2002, p. 452). Success in application of ERP system requires realizing their potential benefits (Chou \& Chang, 2008, p. 150). To stop using of system because of inability to meet the needs of organization is regarded as a failure of ERP application (Markus, Axline, Petrie \& Tanis, 2000, p. 247).

Primary benefits that use of ERP system provides can be classified in 5 sections (Al-Mashari et al., 2003, p. 356).

(1) Operational benefits: Decreasing storage costs, shortening processes, enhancing quality and efficiency, promoting customer services.

(2) Management benefits: Better coordination of resources, improving decision making and planning, cash management and promoting services. 
(3) Strategic benefits: Supporting company's growth, supporting inter-company cooperation, creating environment intended to innovations, realizing cost leadership, going for product differentiation, providing for cyber world for customers and suppliers.

(4) Creating information technology structure: Flexibility of work process, cost savings of information technology, raise information technology structural skill.

(5) Organizational benefits: Supporting for organizational change, helping organizational learning, provide possibility to promote personnel and construction of joint vision.

Brought from a data set of 8 industry and 240 company, the results that attained from researchers, who examine hypothesis of that information technology investments will have positive effects on performance, indicates a relation between information technology investment and performance (Hu \& Quan, 2005, p. 42). In another examination, with participation of 33 valve producer companies, it is found out that information system investments are affecting performance significantly (Weill, 1992, p. 326). Another study of which results are taken from 247 companies reveals the positive affect of ERP application on performance, particularly in active returns, activity income and cost of selling products (Reck, 2004, p. 109). Researchers, testing hypothesis of that ERP success affects perceived organizational performance positively, found evidences supporting statistically in a study in Hong Kong, with participation of 96 companies (Law \& Ngai, 2007, p. 426). In light of these values, following hypothesis will be tested:

$\mathrm{H}_{12}$ : There is a positive correlation between ERP implementation success and perceived organizational performance.

\subsection{Perceived Organizational Performance}

Performance refers to the degree of realization of company's objectives (Choi, Poon \& Davis, 2008, p. 250). These objectives can be economic like market share and growth rate as well as financial objectives like sell outs, profitability, ratio or operational objectives like quality of product or organizational objectives (Short \& Palmer, 2003, p. 210). On the other hand, perceived organizational performance measures information system's effect on company performance (Zviran \& Erlich, 2003, p. 82). Benefits toward improvement in efficiency and performance of company, decreasing in costs, enhancing in quality, raising flexibility, promoting customer satisfaction, higher financial performance are expected with the information technology investment of companies. In a research on 40 companies in insurance industry, positive relation is pointed out between organizational performance and information technology investment (Byrd \& Marshall, 1997, p. 45).Primary benefits, to be taken with the efficient use of ERP systems, are extending information skills, speeding up reporting, integration of administrative functions, improving company performance dependent on redesigning management process (Wall \& Seifert, 2003, p. 2). Success measurements are cost of savings, improvement on customer services, competitive advantage, income raise, increasing general efficiency, enhancing product or service quality (Whyte et al., 1997, p. 38). In a study examining long-run effects of ERP adoptions on company performance by results from 63 companies shows significant improvements in active returns, investment returns and active asset turnover in 3 years run (Hunton, Lippincott \&Reck, 2003, p. 165). Result of Reck's study (2004, p. 107), support that ERP system application contributes to company's financial performance. Poston and Grabski (2001, p. 286), report important improvement in reduction of workers and cost of sell outs by the application of ERP system.

\section{Research Method}

This section sets forth how scopes are being created. Data collecting method will be explained. Factor analyze, validity and reliability, results of hypothesis tests will be presented. Suggestions will be made to constraint of the study and further researches.

\subsection{Scopes Which Belong to Variables}

Firstly, a questionnaire form has been created from gathered questions taken from scopes in literature of which validity and reliability has already been tested. Survey questions are measured with quantitate Likert type scope lining up; 1: strongly disagree, 3: neutral, 5: strongly agree.

First factor generating user characteristics is satisfaction. The questions, which are measuring user satisfaction, are taken from Bradford and Florin (2003, p. 223). Second factor setting of user characteristics is resistance of user. Four questions measuring user resistance are taken from Jiang, Muhanna \& Klein's article (2000, p. 27), and other two questions are taken from Hong \& $\operatorname{Kim}(2002$, p. 38).

First variable, examined as innovative characteristics, is technical compatibility of which questions are taken 
from Bradford \& Florin (2003, p. 223). Second variable is reengineering questions about this variable are taken from Bradford \& Florin (2003, p. 222), Bhatt \& Stump (2001, p. 38), Hong \& Kim (2002, p. 38), Al-Mashari, Irani \& Zairi's studies (2001, p. 445). Questions measuring total quality managements are compiled from Fuentes, Albacete Saez \& Llorens Montes (2004, p. 438). First factor, considering in organizational characteristics, is senior management support of which questions are collected from Ramamurthy \& Premkumar (1995, p. 349) and Premkumar \& Roberts (1999, p. 483). Consensus questions in organizational purposes are developed from Bradford \& Florin (2003, p. 223), Knight, Pearce, Smith, Olian, Sims, Smith \& Flood (1999, p. 464-465) studies. Questions calculating ERP education are adopted from Gyampah \& Salam's (2004, p. 737) article. Used were studies of Porter \& Millar (1995, p. 158) with Thong (1999, p. 198) to measure variable of information intensity. Competitive pressure of which questions is developed from Premkumar \& Roberts (1999, p. 483), Thong \& Yap's (1995, p. 435) studies. Environmental uncertainty questions are benefitted from Sutcliffe \& Huber's (1998, p. 805) study and Fuentes et al. (2004, p. 438) article. Questions measuring ERP application's success are taken from studies of Stratman \& Roth (2002, p. 609), Hong \& Kim (2002, p. 38). Questions measuring perceived organizational performance are adopted from Deloitte Consulting (1999, p. 15), Ramamurthy \& Premkumar (1995, p. 349) and Stenbeck (1998, p. 2).

\subsection{Collecting Data}

The universe of this research is companies using ERP in Turkiye. There is no institution list up ERP users as a whole. So that, list of ERP users gathered from reference lists published on websites of ERP software companies such as SAP, Oracle, Baan, GlobalSoft, Netsis (Fusion ERP), Eta, Mapics, Efes Softare (Pro ERP), Elan, Microsoft (Axapta, Dynamics), Canias, Unitec IFS, Minerva Software (Plantum ERP), Bosphorus Software (Adonix ERP), Link Computer (Sun ERP), Logo, Micro Softwarehouse (MyERP), Likom (Gusto ERP), QAD, Login, Goldion.

Survey questionnaires are posted via mails and e-mails to 610 companies using ERP systems and 236 companies responded. Survey participation ratio is about $40 \% .95 \%$ of the respondents are university graduates. Business titles of those respondents are predominantly "ERP expert" and "Accountant" (82\%). Majority of those firms are big companies ( $70 \%$ in terms of sales volume and $46 \%$ in terms of number of employees) (Note 3 ). $65 \%$ of the firms are active at least 16 years along in their related sectors. Sectorial distribution shares of those firms are as follows: $32 \%$ from metal, $18 \%$ frompetrochemical, $16 \%$ from electricity/electronics, $13 \%$ from textiles, $12 \%$ from services, $10 \%$ from food and $7 \%$ from mining and soil industries. Business experience of the respondentsin years distributed as follows: $1-3$ years: $40 \%, 4-6$ years: $21 \%, 7-11$ years: $23 \%, 12$ years and more: $16 \%$.

\section{Results}

Used scales are strong theoretically and experimentally as they are tested in previous researches. However, it is essential to state how much factor undertakes question, measuring variables anyway. For this purpose heuristic factor analyze (HFA) has been made by using variance maximization method in SPSS software. Testing availability of factor analyze and homogeneity of used variables Kaiser-Meyer-Olkin (KMO) sample adequacy measure and Bartlett test has been benefitted. KMO is an index used to measure adequacy of sample size for factor analyze by means of comparing size of coefficient of observed correlation and coefficient of part correlation. HFA results point out 5 factor structure.KMO 0.901 attained from HFA and Bartlett test value $(\mathrm{p}<0.00)$, expose that analyze results are meaningful (Mitchell, 1994, p. 6). This situation shows that variable in this scale are available for factor analyze. Bartlett test results $(\mathrm{p}<0.000)$ also clearly reveal a relationship between variables in universes (Gaski, 1984, p. 21).To measure used scales reliability and internal consistency Cronbach $\alpha$ coefficient is used. Cronbach $\alpha$ tests scales reliability and internal consistency by measuring differences. All Conbach $\alpha$ coefficients are over 0.70 as it is presented in Table 1. Since Cronbach $\alpha$ values in regard to variable are over correlation values between variables, it can be said that decomposing validity is ensured.

\subsection{Heuristic Factor Analyze}

Since scales used in research created by scanning information system literature, it should be subject to factor analyze. Because great number of questions are used in different cultures and different samples. Reached results present that, as expected, created questions to measure variables are undertaken by factors they are related with. According to structures reached in consequence of factor analyze, it is found out that Cronbach $\alpha$ reliability coefficients in regard to variables are over 0.60 which is consent in literature. It is explained with 2 factors of user satisfaction (explained variance $8.440 \%$ and reliability coefficient 0.860 ) and user resistance (explained variance $20.220 \%$ and reliability coefficient 0.86 ), which are setting off user characteristics. The ratio of total 
variance explanation of user characteristics is $70.298 \%$ (see Table 1).

Table 1. Factor undertake of user characteristics and cronbach alfa values

\begin{tabular}{lll}
\hline User Characteristics (Explanation rate of total variance 70.298\%) & Factor 1 & Factor 2 \\
\hline 1. User Satisfaction (Cronbach $\boldsymbol{\alpha}: \mathbf{0 . 8 6 0}$ ) (Total explained variance: 8.440\%) & 0.742 \\
Set up system is compatible with our expectation. & 0.806 \\
Needed information is attained on time. & 0,795 & 0.800 \\
Content of information meets our needs. & & 0.764 \\
Content of information is reliable. & & 0.870 \\
\hline 2. User Resistance (Cronbach $\boldsymbol{\alpha}: \mathbf{0 . 8 6 4}$ ) (Total explained variance: 20.220\%) & .0832 \\
\hline Workers are afraid of content to be changed in new system. & 0.745 \\
Workers are afraid of losing statue and job in new system. & \\
Users are afraid of uncertainty brought by new system. & \\
Workers are afraid of dismissal in new system. & \\
Many workers show endurance to ERP application. & 0.774 \\
Many workers desired ERP system to be fail. & & 0.620 \\
\hline
\end{tabular}

Innovative characteristics of technical compatibility (explained variance $16.361 \%$ and reliability coefficient 0.867 ), reengineering (explained variance $12.900 \%$ and reliability coefficient 0.742 ), tqm (explained variance $26.191 \%$ and reliability coefficient 0.824 ) are presented. The ratio of total variance explanation of innovative characteristics is $55.452 \%$ (see Table 2).

Table 2. Factor undertake of innovative characteristics and cronbach alfa values

\begin{tabular}{|c|c|c|c|}
\hline $\begin{array}{l}\text { Innovative Characteristics (Ratio of total variance explanation } 55.452 \% \text { ) } \\
\text { 1. Technical Compatibiliy (Cronbach } \alpha: 0.867 \text { ) (total explained variance: } \\
\text { 16.361\%) }\end{array}$ & Factor 1 & Factor 2 & Factor 3 \\
\hline ERP system is compatible with present system. & 0.881 & & \\
\hline ERP system is compatible with present hardware. & 0.854 & & \\
\hline ERP system is compatible with present business applications. & 0.863 & & \\
\hline \multicolumn{4}{|l|}{ 2. Reengineering (Cronbach $\alpha: 0.742$ ) (total explained variance: $12.900 \%$ ) } \\
\hline $\begin{array}{l}\text { Making processes compatible with ERP required time and endeavor } \\
\text { significantly. }\end{array}$ & & 0.446 & \\
\hline During set up of ERP system, work processes are re-designed for simplicity. & & 0.572 & \\
\hline $\begin{array}{l}\text { Making documents compatible with ERP required time and endeavor } \\
\text { significantly. }\end{array}$ & & 0.471 & \\
\hline Roles and responsibilities are changed. & & 0.834 & \\
\hline Skill requirements are changed. & & 0.759 & \\
\hline Non-value-add works eliminated. & & 0.656 & \\
\hline \multicolumn{4}{|l|}{$\begin{array}{l}\text { 3. Total quality management (Cronbach } \alpha: 0.824 \text { ) (total explained } \\
\text { variance: } 26.191 \% \text { ) }\end{array}$} \\
\hline Processes and activities focused on customer satisfaction. & & & 0.686 \\
\hline Managers and consultants incites for customer satisfaction and improvement & & & 0.795 \\
\hline It is very important to meet customers' needs and expectations. & & & 0.811 \\
\hline Improvement in all products, services and processes is incited. & & & 0.737 \\
\hline Teamwork is the expected style of work in this organization. & & & 0.652 \\
\hline $\begin{array}{l}\text { Every worker in organization participates in improvement of products, services } \\
\text { and processes. }\end{array}$ & & & 0.552 \\
\hline
\end{tabular}


HFA results undertake organizational characteristics to four variables. These variables are top management support (explained variance $37.462 \%$ and reliability coefficient 0.73 ), consensus on organizational purposes (explained variance $7.093 \%$ and reliability coefficient 0.742 ), education (explained variance $13.469 \%$ and reliability coefficient 0.883 ), information intensity (explained variance $9.666 \%$ and reliability coefficient 0.762 ) (see Table 3).

Table 3. Factor undertake of organizational characteristics and cronbach alfa values

\begin{tabular}{|c|c|c|c|c|}
\hline $\begin{array}{l}\text { Organizational Characteristics (Ratio of total variance explanation } 67.691 \% \text { ) } \\
\text { 1. Top management support (Cronbach } \alpha: 0.934 \text { ) (total explained variance: } \\
37.462 \% \text { ) }\end{array}$ & Factor 1 & Factor 2 & Factor 3 & Factor 4 \\
\hline $\begin{array}{l}\text { Top management is provided adequate finance, resource and personnel for ERP } \\
\text { application. }\end{array}$ & 0.654 & & & \\
\hline Top management participates in ERP system is strong. & 0.797 & & & \\
\hline Top management takes care of ERP system. & 0.852 & & & \\
\hline Top management supports ERP usage in company activities. & 0.847 & & & \\
\hline Top management takes ERP system as a strategic source. & 0.812 & & & \\
\hline Top management supports adoption of ERP system. & 0.831 & & & \\
\hline \multicolumn{5}{|l|}{$\begin{array}{l}\text { 2. Consensus on Organizational Purposes (Cronbach } \alpha: 0.73 \text { ) (total explained } \\
\text { variance: } 7.093 \% \text { ) }\end{array}$} \\
\hline There was a consensus on special purposes application of ERP started & & 0.779 & & \\
\hline Before using ERP application using reason has been stated briefly and clearly & & 0.781 & & \\
\hline \multicolumn{5}{|l|}{ 3. Education (Cronbach $\alpha: 0.883$ ) (total explained variance: $13.469 \%$ ) } \\
\hline After education program my understanding level of ERP system improved & & & 0.747 & \\
\hline Education on new system gives me confidence & & & 0.825 & \\
\hline Education is detailed and long adequately & & & 0.854 & \\
\hline Educators are intellectual and helped me to understand system & & & 0.801 & \\
\hline \multicolumn{5}{|l|}{ 4. Information intensity (Cronbach $\alpha$ : 0.762 ) (total explained variance: $9.666 \%$ ) } \\
\hline We have got plenty of supplier & & & & 0.719 \\
\hline We have got plenty of customer & & & & 0.653 \\
\hline Selling product requires vast amount of information & & & & 0.725 \\
\hline Production process compose of various steps & & & & 0.813 \\
\hline Production requires long time & & & & 0.631 \\
\hline
\end{tabular}

Competitive pressure (explained variance $42.320 \%$ and reliability coefficient 0.848 ), and environmental uncertainty (explained variance $14.029 \%$ and reliability coefficient 0.762 ) are setting off environmental characteristics. The ratio of total variance explanation of environmental characteristics is $56.349 \%$ (see Table 4 ).

Table 4. Factor undertake of environmental characteristics and cronbach alfa values

\begin{tabular}{|c|c|c|}
\hline $\begin{array}{l}\text { Environmental Characteristics (Ratio of total variance explanation 56,349\%) } \\
\text { 1. Competitive Pressure (Cronbach } \alpha: 0.848 \text { ) (total explained variance: } 42,320 \% \text { ) }\end{array}$ & Factor 1 & Factor2 \\
\hline Customers will prefer rivals unless we adopt ERP & 0.810 & \\
\hline ERP technology must be used to compete in market & 0.758 & \\
\hline Customers demand for ERP technology to do business & 0.841 & \\
\hline Doing business with our supplier requires ERP & 0.793 & \\
\hline \multicolumn{3}{|l|}{ 2. Environmental Uncertainty (Cronbach $\alpha: 0.762)$ (total explained variance: $14,029 \%)$} \\
\hline Customers' demands and preferences are changeable relatively & & 0.588 \\
\hline Our company should change the production type of products/services in order to be competitive & & 0.576 \\
\hline Our company changes its technology frequently in order to handle its rivals & & 0.676 \\
\hline It is hard to estimate rivals behaviors & & 0.613 \\
\hline Our company produces very unique production/service & & 0.747 \\
\hline Rivals tactics and competitions are very different & & 0.684 \\
\hline
\end{tabular}


ERP application success, only intervening variable, has the total variance explanation ratio of $11.430 \%$ and reliability coefficient of 0.899 . Depended variable of the model, perceived organizational performance, has the total variance explanation ratio of $55.107 \%$ and reliability coefficient of 0.951 . ERP application success and perceived organizational performance has the total variance ratio of $56.349 \%$ (see Table 5)

Table 5. Factor undertake of ERP application success and perceived organizational performance and cronbach alfa values

\begin{tabular}{|c|c|c|}
\hline $\begin{array}{l}\text { ERP Implementation Success and Perceived Organizational Performance (Ratio } \\
\text { of total variance explanation } 56.349 \% \text { ) }\end{array}$ & Factor 1 & Factor 2 \\
\hline \multicolumn{3}{|l|}{$\begin{array}{l}\text { ERP Implementation Success } \\
\text { (Cronbach } \alpha: 0.899) \text { (total explained variance: } 11.430 \%)\end{array}$} \\
\hline ERP system improved efficiency of distribution function & 0.556 & \\
\hline Cost of ERP project was over the estimated budget & 0.610 & \\
\hline Performance of ERP system meets the expectations & 0.914 & \\
\hline ERP system is successful & 0.874 & \\
\hline \multicolumn{3}{|l|}{$\begin{array}{l}\text { 2. Perceived Organizational Performance (Cronbach } \alpha: 0.951 \text { ) (total explained } \\
\text { variance: } 55.107 \% \text { ) }\end{array}$} \\
\hline ERP system increased sales & & 0.848 \\
\hline ERP system increased profit & & 0.810 \\
\hline Decreased in process cost & & 0.619 \\
\hline Stock level decreased & & 0.676 \\
\hline Marketshare increased & & 0.865 \\
\hline Contributed to decrease cost of marketing & & 0.737 \\
\hline Contributed to reach budget purpose & & 0.634 \\
\hline
\end{tabular}

\subsection{Correlation Analyzes}

Correlation analyzes are used to determine the direction and relation level between variables. In research, it is confirmed by means of using Pearson coefficient whether there is a relation between variables or not. Pearson coefficient takes values between +1 and -1 . There is a strong relation in positive direction when approaching +1 and negative direction when approaching - 1 . If Pearson coefficient is between 0.70 and 1 , than relations between variables are strong, between $0.70-0.40$ means medium relation and under 0.20 refers to negligible values. The result of analyze presented in Table 6.

Table 6. Descriptive statistics and correlations of variables

\begin{tabular}{|c|c|c|c|c|c|c|c|c|c|c|c|c|c|}
\hline & 1 & 2 & 3 & 4 & 5 & 6 & 7 & 8 & 9 & 10 & 11 & 12 & 13 \\
\hline 1.User & 1.00 & & & & & & & & & & & & \\
\hline \multicolumn{14}{|l|}{ Satisfaction } \\
\hline 2.User & .006 & 1.00 & & & & & & & & & & & \\
\hline \multicolumn{14}{|l|}{ Resistance } \\
\hline 3.Technical & $.537 * *$ & $.277 * *$ & 1.00 & & & & & & & & & & \\
\hline \multicolumn{14}{|l|}{ Compatibility } \\
\hline 4.Reengineering & $.130^{*}$ & -.029 & -.007 & 1.00 & & & & & & & & & \\
\hline 5.Total Quality & $.389 * *$ & $.304 * *$ &, $237 * *$ & $.174 * *$ & 1.00 & & & & & & & & \\
\hline \multicolumn{14}{|l|}{ Management } \\
\hline 6.Top & $.432 * *$ & $.301 * *$ & $.314 * *$ & -.031 & $.448 * *$ & 1.00 & & & & & & & \\
\hline \multicolumn{14}{|l|}{ Management } \\
\hline \multicolumn{14}{|l|}{ Support } \\
\hline 7.Consensus & $.235^{* *}$ & .081 & $.213 * *$ & .073 & $.246 * *$ & $.382 * *$ & 1.00 & & & & & & \\
\hline 8.Education & $.475^{* *}$ & $.365^{* *}$ & $.331 * *$ & .081 & $.367 * *$ & $.525^{* *}$ & $.284 * *$ & 1.00 & & & & & \\
\hline $\begin{array}{l}\text { 9.Information } \\
\text { intensity }\end{array}$ & $.190 * *$ & $.168^{*}$ & .076 & .110 & $.322 * *$ & $.214 * *$ & .075 & $.261 * *$ & 1.00 & & & & \\
\hline $\begin{array}{l}\text { 10.Competitive } \\
\text { Pressure }\end{array}$ & .069 & $.217 * *$ & $.141 *$ & $.271^{* *}$ & .113 & .034 & .031 & $.330 * *$ & $.342 * *$ & 1.00 & & & \\
\hline
\end{tabular}




\begin{tabular}{|c|c|c|c|c|c|c|c|c|c|c|c|c|c|}
\hline \multicolumn{13}{|l|}{ Uncertainty } & \\
\hline 12.ERP & $.524 * *$ & $.437 * *$ & $.442 * *$ & .089 & $.379 * *$ & $.433 * *$ & $.192 * *$ & $.549 * *$ & $.229 * *$ & $.396 * *$ & $.383^{* *}$ & 1.00 & \\
\hline \multicolumn{14}{|l|}{ Implementation } \\
\hline \multicolumn{14}{|l|}{ Success } \\
\hline 13.Perceived & $.409 * *$ & $.307 * *$ & $.363 * *$ & $.274 * *$ & $.295 * *$ & $.184 * *$ & .126 & $.467 * *$ & $.316^{* *}$ & $.577 * *$ & $.498 * *$ & $.598 * *$ & 1 \\
\hline \multicolumn{14}{|l|}{ Organizational } \\
\hline Performance & & & & & & & & & & & & & \\
\hline
\end{tabular}

Note. * Significant at a level of $\mathrm{p}<0.05 ; * *$ Significant at a level of $\mathrm{p}<0.01$.

\subsection{Additional Analysis Related with ERP Implementation Success and Perceived Organizational Performance}

Regression-equation-No.1 which settled for investigating the effects of all the independent variables of the model on the success of ERP implementation success was found as statistically significant ( $F=19.387 ; p<0.01)$. It has been concluded from the research that, there are statistically significant and positive effects of the factors; user satisfaction $(\beta=0.228, p<0.01)$, technical compatibility $(\beta=0.118, p<0.05)$, top management support ( $\beta$ $=0.135, \mathrm{p}<0.05)$, training $(\beta=0.210, \mathrm{p}<0.01)$, competitive pressure $(\beta=0.191, \mathrm{p}<0.01)$ and environmental uncertainty $(\beta=0.142, p<0.05)$ on ERP implementation success. In the examination of $\beta$ parameters, it is found that user satisfaction factor has the greatest impact on ERP implementation success. This factor is followed by training and competitive pressure factors.

Regression-equation-No.2 which settled for investigating the effects of all the independent variables of the model on perceived organizational performance was found as statistically significant $(F=16.730, p<0.01)$. Concluded from the research that, there are statistically significant and positive effects of those factors on ERP implementation success: User satisfaction $(\beta=0.149, \mathrm{p}<0.05)$, training $(\beta=0.243, \mathrm{p}<0.01)$, competitive pressure $(\beta=0.222, \mathrm{p}<0.01)$ and environmental uncertainty $(\beta=0.183, \mathrm{p}<0.01)$. Here, it is seen that, consensus on organizational objectives is statistically significant $(\beta=-0.109, p<0.05)$, even though it affects perceived organizational performance negatively. In the examination of $\beta$ parameters, it is found that training factor has the greatest impact on perceived organizational performance. This factor has been followed by competitive pressure and perceived usefulness factors.

Regression-equation-No.3 which is settled by inserting all the independent variables of the model together with ERP implementation success into regression in order to investigate their total effects on perceived organizational performance was found as statistically significant $(\mathrm{F}=21.233, \mathrm{p}<0.01)$. It has been reached that, there are statistically significant and positive effects of those factors on perceived organizational performance: Re-engineering of work processes $(\beta=0.115, \mathrm{p}<0.05)$, training $(\beta=0.157, \mathrm{p}<0.01)$, competitive pressure $(\beta=$ $0.271, p<0.01)$, environmental uncertainty $(\beta=0.178, p<0.01)$ and ERP implementation success $(\beta=0.232, p$ $<0.01$ ). In particular, top management support effects perceived organizational performance negatively and this is statistically significant $(\beta=-0.133, p<0.05)$. In the examination of $\beta$ parameters, it is found that competitive pressure factor has the highest impact on perceived organizational performance. This factor has been followed by ERP implementation success and environmental uncertainty factors. To show the hypothesis testing results all together will be useful (see Table 7).

Table 7. Results of hypotheses

\begin{tabular}{|c|c|c|}
\hline $\begin{array}{l}\text { Hyp. } \\
\text { No }\end{array}$ & Hypotheses & Result \\
\hline $\mathbf{H}_{1 \mathbf{a}}:$ & There is a positive correlation between user satisfaction and ERP implementation success. & Supported \\
\hline $\mathbf{H}_{1 \mathrm{~b}}$ : & $\begin{array}{l}\text { There is a positive correlation between perceived organizational performance and user } \\
\text { satisfaction. }\end{array}$ & Supported \\
\hline $\mathbf{H}_{2 \mathbf{a}}$ : & There is a negative correlation between user resistance and ERP implementation success. & Supported \\
\hline $\mathbf{H}_{2 \mathrm{~b}}$ : & $\begin{array}{l}\text { There is a negative correlation between user resistance and perceived organizational } \\
\text { performance. }\end{array}$ & Supported \\
\hline $\mathbf{H}_{3 \mathbf{a}}$ : & There is a positive correlation between ERPimplementation success and technical compatibility. & Supported \\
\hline $\mathbf{H}_{3 \mathrm{~b}}$ : & $\begin{array}{l}\text { There is a positive correlation between perceived organizational performance and technical } \\
\text { compatibility. }\end{array}$ & Supported \\
\hline $\mathbf{H}_{4 \mathrm{a}}$ : & There is a positive correlation between reengineering and ERP implementation success. & Supported \\
\hline
\end{tabular}




\begin{tabular}{|c|c|c|}
\hline $\mathbf{H}_{4 \mathrm{~b}}:$ & $\begin{array}{l}\text { There is a positive correlation between reengineering and perceived organizational } \\
\text { performance. }\end{array}$ & Supported \\
\hline $\mathbf{H}_{5 \mathbf{a}}:$ & There is a positive correlation between TQM and ERP implementation success. & Supported \\
\hline $\mathbf{H}_{5 \mathbf{b}}$ : & There is a positive correlation between perceived organizational performance and TQM. & Supported \\
\hline $\mathbf{H}_{6 \mathbf{a}}:$ & $\begin{array}{l}\text { There is a positive correlation between top management support and ERP implementation } \\
\text { success. }\end{array}$ & Supported \\
\hline $\mathbf{H}_{6 \mathrm{~b}}$ : & $\begin{array}{l}\text { There is a positive correlation between top management support and perceived organizational } \\
\text { performance. }\end{array}$ & Supported \\
\hline $\mathbf{H}_{7 \mathbf{a}}:$ & $\begin{array}{l}\text { There is a positive correlation between consensus on organizational purposes and ERP } \\
\text { implementation success. }\end{array}$ & Not Supported \\
\hline $\mathbf{H}_{7 \mathbf{b}}$ : & $\begin{array}{l}\text { There is a positive correlation between consensus on organizational purposes and perceived } \\
\text { organizational performance. }\end{array}$ & Not Supported \\
\hline $\mathbf{H}_{8 \mathrm{a}}$ : & There is a positive correlation between training on and ERP implementation success. & Supported \\
\hline $\mathbf{H}_{8 \mathrm{~b}}$ : & There is a positive correlation between training and perceived organizational performance. & Supported \\
\hline $\mathbf{H}_{9 \mathbf{a}}$ : & There is a positive correlation between information intensity and ERP implementation success. & Not Supported \\
\hline $\mathbf{H}_{9 \mathrm{~b}}$ : & $\begin{array}{l}\text { There is a positive correlation between information intensity and perceived organizational } \\
\text { performance. }\end{array}$ & Supported \\
\hline $\mathbf{H}_{10 \mathrm{a}}$ : & There is a positive correlation between competitive pressure and ERP implementation success. & Supported \\
\hline $\mathbf{H}_{10 \mathrm{~b}}$ : & $\begin{array}{l}\text { There is a positive correlation between competitive pressure and perceived organizational } \\
\text { performance }\end{array}$ & Supported \\
\hline $\mathbf{H}_{11 \mathrm{a}}$ : & $\begin{array}{l}\text { There is a positive correlation between environmental uncertainty and ERP implementation } \\
\text { success. }\end{array}$ & Supported \\
\hline $\mathbf{H}_{11 \mathrm{~b}}$ : & $\begin{array}{l}\text { There is a positive correlation between environmental uncertainty and perceived organizational } \\
\text { performance. }\end{array}$ & Supported \\
\hline $\mathbf{H}_{12}:$ & $\begin{array}{l}\text { There is a positive correlation between ERP implementation success and perceived } \\
\text { organizational performance. }\end{array}$ & Supported \\
\hline
\end{tabular}

\section{Conclusion}

Diffusion of Innovation Theory provides an explanation to the determiners of the use of information system. Investigation of the effects of DOI parameters on ERP implementation success and organizational performance consists the main objective of this study. There is a need for researchers who can generalize accuracy and applicability of the Diffusion of Innovation to maximize potential benefits. Major contribution of this article to science is that it reveals effects of variables of the DOI Theory on adoption of enterprise resource planning, because contribution of academic literature is a well-planned theory in developing ERP systems (Holland \& Light, 2001, p. 43). According to the DOI Theory, companies should carry into practice when they made decision of investment on information systems by considering four factor groups. In another words, variables which affect adoption of information system's success in companies are user characteristics, innovation characteristics, organizational characteristics and environmental characteristics. In this study, 13 variables have been examined representing aforementioned characteristics.

It is people who enter inputs and use outputs of the system. So, user factor is important. It is needed to be announced that set up information system is user friendly, easy to learn, having positive effects on users' tasks. The possibility of resistance of users against system always should be regarded and management application should become realize to eliminate aforementioned factor. Managers of the firms should know that they will be able to improve their own corporate capabilities by such a way when they decide about setting an ERP information system within the firm. The unique managing tool is ERP system which can support the use of competitive strategies like supply chain, sales chain, electronic commerce. It enables the facility to use the information at a firm-wide level and to improve its quality. It serves for making right decisions by providing support for this process.

Companies, which are selling ERP, should concentrate on technical compatibility. It should be mentioned that ERP system is compatible with present values of organizations. ERP set up requires reengineering of work process and implementation of TQM philosophy. Aforementioned management tools are supporting each other. These tools affect both ERP application success and organizational performance positively. Top managers should take active role in ERP system. One of the key points of success is administrator's incentive attitude toward transition and use of system. They should finance and provide for needed resources. It is an undoubted reality that education has a great role on ERP application success and organizational performance. Education 
affects organizational performance and ERP application success at the same time. The need for management of information attained from products is another reason for adoption of ERP information system. Aforementioned situation, in other words information intensity, should always be regarded. Global competition is unavoidable in production and selling of advanced technological products. Thereby, there is need for ERP application's benefits in use and management of information.

Another important finding of his article is that existence of environmental uncertainty and competitive pressure are the motivations of companies for ERP systems. ERP dealers should focus on industries that competitive pressure and uncertainty of environment are intensive. It should be pointed out that companies, adopted ERP system, can take advantage of competitive pressure variable. It should be told that ERP system will not differentiate users but its change nature of competition. Eliminating uncertainty of environment is possible with ERP systems. Organization's administrator can take advantage of competition and uncertainty risks by steering for ERP technology and application of ERP system. Immediately, management should prefer and use the most popular ERP system as an information system in industry in which company is active. By that, organization's ability of adoption to environmental changes has a role on surviving. There are points that managers should consider in set up and apply of ERP technology to the organization. First of all, the reasons of steering for ERP software and benefits that will be taken from system should be noticed. Secondly, problems with current processes should be regarded.

A detailed study should be done in order to meet needs for reengineering process that ERP software requires for. Besides that, TQM applications are to be proceeded as long as company says active. Lastly, planning and managing information system's budget is important subject referring to reconstitution and training needs caused by set up of ERP information system function. The use of ERP systems effects organizational performance in a positive and significant level. A more intensive use of information system will improve organizational performance.

Authors, hopes for a contribution to philosophy of the DOI Theory by inciting similar research initiatives of ideas that article include.

\section{References}

Adams, B., Berner, E., \& Rousse, J. (2004). Applying Strategies to Overcome User Resistance in a Group of Clinical Managers to a Business Software Application: A Case Study. Journal of Organizational and User Computing, 16(4), 55-64. http://dx.doi.org/10.4018/joeuc.2004100104

Adamson, I., \& Shine, J. (2003). Extending The New Technology Acceptance Model to Measure The End User Information Systems Satisfaction in a Mandatory Environment: A Bank's Treasury. Technology Analysis \& Strategic Management, 15(4), 441-455. http://dx.doi.org/10.1080/095373203000136033

Ahadi, H. (2004). An Examination of The Role of Organizational Enablers in Business Process Reengineering and The Impact of Information Technology. Information Resources Management Journal, 17(4), 1-19. http://dx.doi.org/10.4018/irmj.2004100101

Al-Mashari, M., Al-Mudimigh, A., \& Zairi, M. (2003). Enterprise Resource Planning: A Taxonomy of Critical Factors. European Journal of Operational Research, 146(2), 352-364. http://dx.doi.org/10.1016/S0377-2217(02)00554-4

Al-Mashari, M., Irani, Z., \& Zairi, M. (2001). Business Process Reengineering: A Survey of International Experience. Business Process Management Journal, 7(5), 437-455. http://dx.doi.org/10.1108/14637150110406812

Ashill, N., \& Jobber, D. (1999). The Impact of Environmental Uncertainty Perceptions, Decision Maker Characteristics and Work Environment Characteristics on The Perceived Usefulness of Marketing Information Systems (MkIS): A Conceptual Framework. Journal of Marketing Management, 15, 519-540. http://dx.doi.org/10.1362/026725799785045815

Au, A. K., \& Enderwick, P. (2000). A Cognitive Model on Attitude Towards Technology Adoption. Journal of Managerial Psychology, 15(4), 266-282. http://dx.doi.org/10.1108/02683940010330957

Au, N., Ngai, E. W. T., \& Cheng, T. C. E. (2002). A Critical Review of End User Information System Satisfaction Research and a New Research Framework. Omega, 30, 451-478. http://dx.doi.org/10.1016/S0305-0483(02)00054-3

Bhatt, G. D., \& Stump, R. L. (2001). An Empirically Derived Model of The Role IS Networks in Business Process Improvement Initiatives. Omega, 29(1), 29-48. http://dx.doi.org/10.1016/S0305-0483(00)00029-3 
Birley, S., \& Westhead, P. (1990). Growth and Performance Contrasts Between "Types" of Small Firms. Strategic Management Journal, 11(7), 535-557. http://dx.doi.org/10.1002/smj.4250110705

Boone, J. (2000). Competitive Pressure: The Effects on Investments in Product and Process Innovation. The RAND Journal of Economics, 31(3), 549-569. Retrieved from http://arno.uvt.nl/show.cgi?fid=2589

Bourgeois, L. J. (1985). Strategic Goals, Perceived Uncertainty and Economic Performance in Volatile Environments. Academy of Management Journal, 28, 548-573. http://www.jstor.org/stable/256113

Bradford, M., \& Florin, J. (2003). Examining The Role of Innovation Diffusion Factors on The Implementation Success of Enterprise Resource Planning Systems. International Journal of Accounting Information Systems, 4(3), 205-225. http://dx.doi.org/10.1016/S1467-0895(03)00026-5

Brandyberry, A. A. (2003). Determinants of Adoption for Organisational Innovations Approaching Saturation. European Journal of Innovation http://dx.doi.org/150-158.10.1108/14601060310486226

Buchko, A. A. (1994). Conceptualization and Measurement of Environmental Uncertainty: An Assessment of the Miles and Snow Perceived Environmental Uncertainty Scale. Academy of Management Journal, 37(2), 410-425. http://dx.doi.org/10.2307/256836

Byrd, T. A., \& Marshall, T. E. (1997). Relating Information Technology Investment to Organizational Performance: A Causal Model Analysis. Omega, 25(1), 43-56. http://dx.doi.org/10.1016/S0305-0483(96)00040-0

Calantone, R. J., Çavuşgil, S. T., \& Zhao, Y. (2002). Learning Orientation, Firm Innovation Capability and Firm Performance. Industrial Marketing Management, 31(6), 515-524. http://dx.doi.org/10.1016/S0019-8501(01)00203-6

Choe, J. M., Lee, Y. H., \& Park, K. C. (1998). The Relationship Model Between The Influence Factors and The Strategic Applications of Information Systems. Eurepean Journal of Information Systems, 7(2), 137-149. Retrieved from http://www.ingentaconnect.com/content/pal/0960085x/1998/00000007/00000002/3000297

Choi, B., Poon, S. K., \& Davis, J. G. (2008). Effects of Knowledge Management Strategy on Organizational Performance: A Complementarity Theory Based Approach. Omega, 36(2), 235-251. http://dx.doi.org/10.1016/j.omega.2006.06.007

Chou, S. W., \& Chang, Y. C. (2008). The Implementation Factors That Influence The ERP Benefits. Decision Support Systems, 46(1), 149-157. http://dx.doi.org/10.1016/j.dss.2008.06.003

Chung, S. H., \& Snyder, C. A. (2000). ERP Adaption: A Technological Evoluation Approach. International Journal of Agile Management Systems, 2(1), 24-32. http://dx.doi.org/10.1108/14654650010312570

Cohen, J. F. (2001). Environmental Uncertainty and Managerial Attitude: Effects on Strategic Planning, Non Strategic Decision Making and Organisational Performance. South Africa Journal of Business Management, 32(3), 17-31.

Cronbach, L. J. (2004). My Current Thoughts on Coefficient Alpha and Successor Procedures (University of California. CSE Report 643). Retrieved from https://www.cse.ucla.edu/products/reports/r643.pdf

Dale, B. G., \& Cooper, C. L. (1994). Introducing TQM: The Role of Senior Management. Management Decision, 32(1), 20-26. http://dx.doi.org/10.1108/00251749410050660

Dasgupta, S., Granger, M., Mcgarry, N. (2002). User Acceptance of E-Collaboration Technology: An Extension of The Technology Acceptance Model. Group Decision and Negotiation, 11, 87-100. http://dx.doi.org/10.1023/A:1015221710638

Deloitte Consulting. (1999). ERP's Second Wave: Maximizing The Value of ERP-Enabled Processes. Retrieved from http://www.deloitte.com/publications/m0499_1.html

Dess, G. G. (1987). Consensus on Strategy Formulation and Organizational Performance: Competitors in a Fragmented Industry. Strategic Management Journal, 8(3), 259-277. http://dx.doi.org/10.1002/smj.4250080305

Dess, G. G., \& Origer, N. K. (1987). Environment, Structure and Consensus in Strategy Formulation: A Conceptual Integration. Academy of Management Review, 12(2), 313-330. http://dx.doi.org/10.5465/AMR.1987.4307943

Dess, G. G., \& Priem, R. L. (1995). Consensus Performance Research: Theoretical and Empirical Extensions. 
Journal of Management Studies, 32(4), 401-417. http://dx.doi.org/10.1111/j.1467-6486.1995.tb00782.x

Dixon, J. R., Arnold, P., Heineke, J., Kim, J. S., \& Mulligan, P. (1994). Business Process Reengineering: Improving in New Srategic Directions. California Management Review, 36(4), 93-108.

Dooley, R. S., Fryxell, G. E., \& Judge, W. Q. (2000). Belaboring The Not-So-Obvious: Consensus, Commitment and Strategy Implementation Speed and Success. Journal of Management, 26(6), 1237-1257. http://dx.doi.org/10.1016/S0149-2063(00)00081-7

Ettlie, J. E. (1983). Organizational Policy and Innovation Among Suppliers to the Food Processing Sector. Academy of Management Journal, 26(1), 27-44. http://dx.doi.org/10.2307/256133

Fichman, R. G. (2001). The Role of Aggregation in The Measurement of IT Related Organizational Innovation. MIS Quarterly, 25(4), 427-455. http://dx.doi.org/10.2307/3250990

Frambach, R. T. (1993). An Integrated Model of Organizational Adoption and Diffusion of Innovations. European Journal of Marketing, 27(5), 22-41. http://dx.doi.org/10.1108/03090569310039705

Frambach, R. T., \& Schillewaert, N. (2002). Organizational Innovation Adoption A Multi-level Framework of Determinants and Opportunities for Future Research. Journal of Business Research, 55(2), 163-176. http://dx.doi.org/10.1016/S0148-2963(00)00152-1

Fuentes, M. M., Albacete-Saez, C. A., \& Llorens-Montes, F. J. (2004). The Impact of Environmental Characteristics on TQM Principles and Organizational Performance. Omega, 32(6), 425-442. http://dx.doi.org/10.1016/j.omega.2004.02.005

Gaski, J. F. (1984). The Theory of Power and Conflict in Channels of Distribution. Journal of Marketing, 48(3), 9-29. http://www.jstor.org/stable/1251326

Gelderman, M. (1998). The Relation Between User Satisfaction Usage of Information Systems and Performance. Information \& Management, 34(1), 11-18. http://dx.doi.org/10.1016/S0378-7206(98)00044-5

Grover, V., Teng, J., Segars, A. H., \& Fiedler, K. (1998). The Influence of Information Technology Diffusion and Business Process Change on Perceived Productivity: The IS Executive's Perspective. Information \& Management, 34(3), 141-159. http://dx.doi.org/10.1016/S0378-7206(98)00054-8

Gyampah, K. A., \& Salam, A. F. (2004). An Extension of The Technology Acceptance Model in an ERP Implementation Environment. Information \& Management, 41, 731-745. http://dx.doi.org/10.1016/j.im.2003.08.010

Hammer, M., \& Champy, J. (1993). Reengineering The Corporation: A Manifesto for Business Revolution. New York, United States of America: Harper Collins Publishers.

Hirschheim, R., \& Newman, M. (1988). Information Systems and User Resistance: Theory and Practice. The Computer Journal, 31(5), 398-408. http://dx.doi.org/10.1093/comjnl/31.5.398

Holland, C. P., \& Light, B. (2001). A Stage Maturity Model for Enterprise Resource Planning Systems Use. Database for Advances in Information Systems, 32(2), 34-45. http://dx.doi.org/10.1145/506732.506737

Hong, K. K., \& Kim, Y. G. (2002). The Critical Success Factors for ERP Implementation: An Organizational Fit Perspective. Information \& Management, 40(1), 25-40. http://dx.doi.org/10.1016/S0378-7206(01)00134-3

Hoque, Z. (2004). A Contingency Model of The Association Between Strategy, Environmental Uncertainty and Performance Measurement: Impact on Organizational Performance. International Business Review, 13(4), 485-502. http://dx.doi.org/10.1016/j.ibusrev.2004.04.003

Hrebiniak, L. G., \& Snow, C. C. (1982). Top Management Agreement and Organizational Performance. Human Relations, 35(12), 1139-1157. http://dx.doi.org/10.1177/001872678203501205

Hsu, C. (2008). Knowledge Sharing Practices as a Facilitating Factor for Improving Organizational Performance Through Human Capital: A Preliminary Test. Expert Systems with Application, 35, 1316-1326. http://dx.doi.org/10.1016/j.eswa.2007.08.012

Hu, Q., \& Quan, J. J. (2005). Evaluating The Impact of IT Investments on Productivity: A Causal Analysis at Industry Level. International Journal of Information Management, 25(1), 39-53. http://dx.doi.org/10.1016/j.ijinfomgt.2004.10.006

Hult, G. T. M., Hurley, R. F., \& Knight, G. A. (2004). Innovativeness: Its Antecedents and Impact on Business $\begin{array}{lrr}\text { Performancer } & \text { Industrial } & \text { Marketing } \\ \mathrm{http} / / \text { dx.doi.org/10.1016/j.indmarman.2003.08.015 }\end{array}$ 
Hunton, J. E., Lippincott, B., \& Reck, J. L. (2003). Enterprise Resource Planning Systems: Comparing Firm Performance of Adopters and Nonadopters. International Journal of Accounting Information Sytems, 4, 165-184. http://dx.doi.org/10.1016/S1467-0895(03)00008-3

Igbaria, M., \& Tan, M. C. (1997). The Consequences of Information Technology Acceptance on Subsequent Individual Performance. Information \& Management, 32(3), 113-121. http://dx.doi.org/10.1016/S0378-7206(97)00006-2

Jiang, J. J., Muhanna, W. A., \& Klein, G. (2000). User Resistance and Strategies for Promoting Acceptance Across System Types. Information \& Management, 37(1), 25-36. http://dx.doi.org/10.1016/S0378-7206(99)00032-4

Kassicieh, S. K., \& Yourstone, S. A. (1998). Training, Performance Evaluation, Rewards and TQM Implementation Success. Journal of Quality Management, 3(1), 25-38. http://dx.doi.org/10.1016/S1084-8568(99)80102-3

Keen, P. G. W. (1994). Every Manager's Guide to Information Technology (2nd ed.). Boston, United States of America: Harvard Business School Press.

Keogh, W., \& Bower, D. J. (1997). Total Quality Management and Innovation: A Pilot Study of Innovative Companies in The Oil and Gas Industry. Total Quality Management, 8(2\&3), 196-201. http://dx.doi.org/10.1080/09544129710008

Knight, D., Pearce, C. L., Smith, K. G., Olian, J. D., Sims, H. P., Smith, K. A., \& Flood, P. (1999). Top Management Team Diversity, Group Process and Strategic Consensus. Strategic Management Journal, 20 , 445-465. http://dx.doi.org/10.1002/(SICI)1097-0266(199905)20:5<445::AID-SMJ27>3.0.CO;2-V

Knol, W. H. C., \& Stroeken, J. H. M. (2001). The Diffusion and Adoption of Information Technology in Small and Medium-sized Enterprises Through IT Scenarios. Technology Anaysis \& Strategic Management, 13(2), 227-246. http://dx.doi.org/10.1080/09537320123815

Kuei, C. H., Madu, C. N., Lin, C., \& Lu, M. H. (1995). An Empirical Investigation of The AssociationBetween Quality Management Practices and Organizational Climate. InternationalJournal of Quality Science, 2(2), 121-137. http://dx.doi.org/10.1108/13598539710167104

Law, C. C. H., \& Ngai, E. W. T. (2007). ERP Systems Adoption: An Exploratory Study of The Organizational Factors and Impacts of ERP Success. Information \& Management, 44(4), 418-432. http://dx.doi.org/10.1016/j.im.2007.03.004

Legris, P., Ingham, J., \& Collerette, P. (2003). Why Do People Use Information Technology? A Critical Review of The Technology Acceptance Model. Information \& Management, 40(3), 191-204. http://dx.doi.org/10.1016/S0378-7206(01)00143-4

Li, E. Y. (1997). Perceived Importance of Information System Success Factors: A Meta Analysis of Group Differences. Information \& Management, 32(1), 15-28. http://dx.doi.org/10.1016/S0378-7206(97)00005-0

Lucas, H. C., \& Spitler, V. K. (1999). Technology Use and Performance: A Field Study of Broker Workstations. Decision Sciences, 30(2), 291-311. http://dx.doi.org/10.1111/j.1540-5915.1999.tb01611.x

Mabert, V. A., Soni, A., Venkataramanan, M. A. (2001). Enterprise Resource Planning: Common Myths Versus Evolving Reality. Business Horizons, 44(3), 69-76. http://dx.doi.org/10.1016/S0007-6813(01)80037-9

Majanja, M. K. M., \& Kiplang'at, J. (2005). The Diffusion of Innovations Theory as a Theoretical Framework in Library and Information Science Research. South African Journal of Libraries \& Information Science, 71(3), 211-224. http://reference.sabinet.co.za/sa_epublication_article/liasa_v71_n3_a1

Markus, M. L., Axline, S., Petrie, D., \& Tanis, C. (2000). Learning From Adopters' Experiences with ERP: Problems Encountered and Success Achieved. Journal of Information Technology, 15, 245-265. http://dx.doi.org/10.1080/02683960010008944

Martinko, M. J., Zmud, R. W., \& Henry, J. W. (1996). An Attributional Explanation of Individual Resistance to The Intoduction of Information Technologies in The Workplace. Behaviour \& Information Technology, 15(5), 313-330. http://dx.doi.org/10.1080/014492996120085a

Martinsons, M. G., \& Chong, P. K. C. (1999). The Influence of Human Factors and Specialist Involvement on Information Systems Success. Human Relations, 52(1), 123-152. http://dx.doi.org/10.1177/001872679905200107 
Mentzer, J. T., \& Konrad, B. P. (1991). An Efficiency/Effectiveness Approach to Logistics Performance Analysis. Journal of Business Logistics, 12(1), 33-62. http://trid.trb.org/view.aspx?id=340577

Mitchell, V. W. (1994). How to Identify Psychographic Segments: Part I. Marketing Intelligence and Planning, 12(7), 4-10. http://dx.doi.org/10.1108/EUM0000000003905

Montalvo, C. (2006). What Triggers Change and Innovation? Technovation, 26(3), 312-323. http://dx.doi.org/10.1016/j.technovation.2004.09.003

Motwani, J., Mirchandani, D., Madan, M., \& Gunasekaran, A. (2002). Successful Implementation of ERP Projects: Evidence From Two Case Studies. International Journal of Production Economics, 75(1\&2), 83-96. http://dx.doi.org/10.1016/S0925-5273(01)00183-9

Murray, C. E. (2009). Diffusion of Innovation Theory: A Bridge for The Research Practice Gap in Counseling. Journal of Counseling \& Development, 87(1), 108-116. http://dx.doi.org/10.1002/j.1556-6678.2009.tb00556.x

Ngai, E. W. T., Law, C. C. H., \& Wat, F. K. T. (2008). Examining The Critical Success Factors in The Adoption of Enterprise Resource Planning. Computers in Industry, 59(6), 548-564. http://dx.doi.org/10.1016/j.compind.2007.12.001

Ollila, E. M., \& Lyytinen, K. (2003). Why Organizations Adopt Information System Process Innovations: A Longitudinal Study Using Diffusion of Innovation Theory. Information Systems Journal, 13(3), 275-297. http://dx.doi.org/10.1046/j.1365-2575.2003.00141.x

Ostroff, C., \& Schmitt, N. (1993). Configurations of Organizational Effectiveness and Efficiency. Academy of Management Journal, 36(6), 1345-1361. http://dx.doi.org/10.2307/256814

Palvia, S. C., Sharma, R. S., \& Conrath, D. W. (2001). A Socio Technical Fremework for Quality Assessment of Computer Information Systems. Industrial Management \& Data Systems, 101(5), 237-251. Retrieved from http://papers.ssrn.com/sol3/papers.cfm?abstract_id=2285861

Pearson, J. M., McCahon, C. S., \& Hightower, R. T. (1995). Total Quality Management: Are Information Systems Managers Ready? Information \& Management, 29(5), 251-263. http://dx.doi.org/10.1016/0378-7206(95)00028-0

Porter, M. E., \& Millar, V. E. (1995). How Information Gives You Competitive Advantage?.Harvard Business Review, 73(4), 149-160. Retrieved from http://zaphod.mindlab.umd.edu/docseminar/pdfs/porter85.pdf

Poston, R., \& Grabski, S. (2001). Financial Impacts of Enterprise Resource Planning Implementations. International Journal of Accounting Information Sytems, 2(4), 271-294. http://dx.doi.org/10.1016/S1467-0895(01)00024-0

Premkumar, G., \& Roberts, M. (1999). Adoption of New Information Technologies in Rural Small Businesses. Omega, 27(4), 467-484. http://dx.doi.org/10.1016/S0305-0483(98)00071-1

Ragu-Nathan, B. S., Apigian, C. H., Ragu-Nathan, T. S., \& Tu, Q. (2004). A Path Analytic Study of The Effect of Top Management Support for Information Systems Performance. Omega, 32(6), 459-471. http://dx.doi.org/10.1016/j.omega.2004.03.001

Ramamurthy, K. (1994). Moderating Influences of Organizational Attitude and Compatibility on Implementation Success From Computer Integrated Manufacturing Technology. International Journal of Production Research, 32(10), 2251-2273. http://dx.doi.org/10.1080/00207549408957066

Ramamurthy, K., \& Premkumar, G. (1995). Determinants and Outcomes of Electronic Data Interchange Diffusion. IEEE Transactions on Engineering Management, 42(4), 332-351. http://dx.doi.org/10.1109/17.482083

Raymond, L., Bergeron, F., \& Rivard, S. (1998). Determinants of Business Process Reengineering Success in Small and Large Enterprises: An Empirical Study in The Canadian Context. Journal of Small Business Management, 36(1), 72-85.

Reck, J. L. (2004). Discussion of: Firm Performance Effects in Relation to The Implementation and Use of Enterprise Resource Planning Systems. Journal of Information Systems, 18(2), 107-110. https://www.zotero.org/groups/implantacionerp/items/itemKey/JAETKF8A

Rogers, E. M. (2003). Diffusion of Innovations (5th ed.). New York, United States of America: Free Press.

Sheu, C., Chae, B., \& Yang, C. L. (2004). National Differences and ERP Implementation: Issues and Challenges. 
Omega, 32, 361-371. http://dx.doi.org/10.1016/j.omega.2004.02.001

Short, J. C., \& Palmer, T. B. (2003). Organizational Performance Referents: An Empirical Examination of Their Content and Influences. Organizational Behavior and Human Decision Processes, 90(2), 209-224. http://dx.doi.org/10.1016/S0749-5978(02)00530-7

Siriginidi, S. R. (2000). Enterprise Resource Planning in Reengineering Business. Business Process Management Journal, 6(5), 376-391. http://dx.doi.org/10.1108/14637150010352390

Somers, T. M., Nelson, K., \& Karimi, J. (2003). Confirmatory Factor Analysis of The End User Computing Satisfaction Instrument: Replication within an ERP Domain. Decision Sciences, 34(3), 595-621. http://dx.doi.org/10.1111/j.1540-5414.2003.02428.x

Stanwick, P. A., \& Pleshko, L. P. (1995). Relationships of Environmental Characteristics, Formalized Planning and Organizational Design to Performance. International Journal of Organizational Analysis, 3(2), 175-197. http://dx.doi.org/10.1108/eb028829

Stenbeck, J. (1998). Quantum Leap Forward. Evolving Enterprise, 1(2), 1-9. Retrieved from http://www.lionhrtpub.com/ee/ee-summer98/toc.html

Stratman, J. K., \& Roth, A. V. (2002). Enterprise Resource Planning (ERP) Competence Constructs: Two-Stage Multi-Item Scale Development and Validation. Decision Sciences, 33(4), 601-628. http://dx.doi.org/10.1111/j.1540-5915.2002.tb01658.x

Sutcliffe, K. M., \& Huber, G. P. (1998). Firm and Industry as Determinants of Executive Perceptions of The $\begin{array}{lllll}\text { Environment. Strategic } & \text { Management }\end{array}$ http://dx.doi.org/10.1002/(SICI)1097-0266(199808)19:8<793::AID-SMJ980>3.0.CO;2-Y

Tait, P., \& Vessey, I. (1988). The Effect of User Involvement on System Success: A Contingency Approach. MIS Quarterly, 12(1), 91-108. http://www.jstor.org/stable/248809

Thong, J. Y. L. (1999). An Integrated Model of Information Systems Adoption in Small Businesses. Journal of Management Information Systems, 15(4), 187-214. Retrieved from http://papers.ssrn.com/sol3/papers.cfm?abstract_id $=1977980$

Thong, J. Y. L., \& Yap, C. S. (1995). CEO Characteristics, Organizational Characteristics and Information Technology Adoption in Small Business. Omega, 23(4), 429-442. http://dx.doi.org/10.1016/0305-0483(95)00017-I

Thong, J. Y. L., Yap, C. S., \& Raman, K. S. (1996). Top Management Support, External Expertise and Information Systems Implementation in Small Businesses. Information Systems Research, 7(2), 248-267. http://dx.doi.org/10.1287/isre.7.2.248

Thornhill, S. (2006). Knowledge, Innovation and Firm Performance in High and Low Technology Regimes. Journal of Business Venturing, 21(5), 687-703. http://dx.doi.org/10.1016/j.jbusvent.2005.06.001

Umble, E. J., Haft, R. R., \& Umble, M. M. (2003). Enterprise Resource Planning: Implementation Procedures and Critical Success Factors. European Journal of Operational Research, 146(2), 241-257. http://dx.doi.org/10.1016/S0377-2217(02)00547-7

Wall, F., \& Seifert, F. (2003). 6th European Conference on Accounting Informations Systems (ECAIS) Does The Structure of an Organization Influence of Its ERP Systems? Results of an Empirical Study. In Lymer, A. (Ed.), Congress Reports Book (p. 1-27). Sevilla, Spain: European Accounting Association.

Wang, E. T. G. (2001). Linking Organizational Context with Structure: A Preliminary Investigation of The Information Processing View. Omega, 29(5), 429-443. http://dx.doi.org/10.1016/S0305-0483(01)00036-6

Weill, P. (1992). The Relationship Between Investment in Information Technology and Firm Performance: A Study of The Valve Manufacturing Sector. Information System Research, 3(4), 307-333. Retrieved from http://www.jstor.org/stable/23010645

Wejnert, B. (2002). Integrating Models of Diffusion of Innovations: A Conceptual Framework. The Annual Review of Sociology, 28, 297-326. http://dx.doi.org/10.1146/annurev.soc.28.110601.141051

Whyte, G., Bytheway, A., \& Edwards, C. (1997). Understanding User Perceptions of Information Systems Success. The Journal of Strategic Information Systems, 6(1), 35-68. http://dx.doi.org/10.1016/S0963-8687(96)01054-2

Woodroof, J., \& Burg, W. (2003). Satisfaction/Dissatisfaction: Are Users Predisposed? Information \& 
Management, 40(4), 317-324. http://dx.doi.org/10.1016/S0378-7206(02)00013-7

Zhang, L., Lee, M. K. O., Zhang, Z., \& Banerjee, P. (2003). Critical Success Factors of Enterprise Resource Planning Systems Implementation Success in China, Proceedings Book. Hawaii, Haiti: IEEE Computer Society. http://dx.doi.org/10.1109/HICSS.2003.1174613

Zhang, Z., Lee, M. K. O., Huang, P., Zhang, L., \& Huang, X. (2005). A Framework of ERP Systems Implementation Success in China: An Empirical Study. International Journal of Production Economics, 98(1), 56-80. http://dx.doi.org/10.1016/j.ijpe.2004.09.004

Zviran, M. (2003). User Satisfaction in ERP System: Some Empirical Evidence. Journal of Academy of Business and Economics, 2(1), 1-23. Retrieved from http://www.freepatentsonline.com/article/Journal-Academy-Business-Economics/113563625.html

Zviran, M., \& Erlich, Z. (2003). Measuring IS User Satisfaction: Review and Implications. Communications of The Association for Information Systems, 12, 81-103. Retrieved from http://web.a.ebscohost.com/ehost/pdfviewer/pdfviewer?sid=70fc6b03-abc8-4693-972a-05177ae846f5\%40s essionmgr4004\&vid=1\&hid=4112

\section{Notes}

Note 1. Efficiency points out to ratio of input and output (Ostroff \& Schmitt, 1993, p. 1345). The term of efficiency used here can be defined as affection of information systems on organizational performance, contribution level to succession of organizational objective (Thong, Yap \& Raman, 1996, p. 252). Grover, Teng Segars and Fiedler (1998, p. 145) states that efficiency is bringing change in abilities on process, in mission roles and job streams. Measurement of efficiency $=$ Estimated consumption of resource/Real consumed resource.

Efficiency of information system: The ability of information system to organization in maximizing income with consumed resources ( $\mathrm{Li}, 1997$, p. 17). Income is possible in sell outs, investments and returns on assets.

Note 2. Effectiveness: Degree of succession on objective (Mentzer \& Konrad, 1991, p. 34). It is measured by calculating increase in sellouts, market shares, customer satisfaction, and product quality in terms of rivals. Measurement of activity $=$ Real output/Estimated output.

Activity of information system: The capacity of information system on definition of what to do to resolve the problems emerged in organization.

Note 3. The definition of Small and Medium Industry Development Organization (KOSGEB) is used for classification of companies. Micro companies, employing less than 10 workers (1-9 workers) and annual net sales are less than 1 million Turkish Liras; small scale enterprise, employing less than 50 workers (10-49 workers) and annual net sales less than 5 million; middle scale enterprise, employing less than 250 workers (50-249 workers) and annual net sales are less than 25 million Turkish Liras; and grand companies of which scale are above all of this.

\section{Copyrights}

Copyright for this article is retained by the author(s), with first publication rights granted to the journal.

This is an open-access article distributed under the terms and conditions of the Creative Commons Attribution license (http://creativecommons.org/licenses/by/3.0/). 